\title{
АБСОЛЮТНО-ВИЗНАЧЕНІ ПОКАРАННЯ ЗА ЗЛОЧИНИ ПРОТИ СТАТЕВОЇ СВОБОДИ ТА СТАТЕВОЇ НЕДОТОРКАНОСТІ
}

ORCID ID: 0000-0002-0600-717X

канд. юрид. наук, доцент кафедри кримінального права

та кримінально-правових дисциплін

Полтавський юридичний інститут

Національного юридичного університету імені Ярослава Мудрого

УКРАÏHA

Законом України «Про внесення змін до деяких законодавчих актів України щодо впровадження Єдиного реєстру осіб, засуджених за злочини проти статевої свободи та статевої недоторканості малолітньої особи, та посилення відповідальності за злочини, вчинені проти статевої свободи та статевої недоторканості малолітньої особи» № 409-IX від 19.12.2019 р. ст. 152 і ст. 153 КК України були доповнені частинами шостими, у яких передбачається відповідальність за повторне зґвалтування (сексуальне насильство), вчинене щодо малолітньої особи. При цьому санкції цих кримінально-правових норм законодавець сорормулював як «караються позбавленням волі на строк п'ятнадцять років або довічним позбавленням волі». По-суті, законодавець запровадив «революційну» новелу, яка полягає у тому, що у КК з'явилося основне покарання у виді позбавлення волі на чітко-визначений термін - 15 років. Подібних покарань у КК України 2001 р. досі не існувало. Всі санкції статей Особливої частини КК України, окрім досліджуваних, побудовані таким чином, що при вирішенні питання про застосування покарання за вчинене кримінальне правопорушення, суддя визначає його в межах своїх дискреційних повноважень. Переважна більшість санкцій кримінально-правових норм Особливої частини кримінального законодавства мають вигляд альтернативних відносно-визначених. Наприклад, санкція ч. 1 ст. 289 КК України сфрормульована як «карається обмеженням волі на строк від трьох до п'яти років або позбавленням волі на той самий строк». Відтак, при призначенні покарання в межах цієї санкції, суд, по-перше, обирає між менш суворим покаранням обмеженням волі і більш суворим - позбавленням волі, a, по-друге, визначається 3 конкретним строком обраного покарання, виходячи 3 мінімального і максимального їх розміру (припускаємо, обмеження волі) - в межах від трьох до п'яти років. Якщо ми поглянемо на санкції частини другої та третьої цієї ж статті, то бачимо, що межи дискреційних повноважень дещо звужуються за рахунок того, що замість двох основних покарань передбачається лише одне - позбавлення волі, терміни якого збільшуються 3 огляду на тяжкість вчиненого посягання. Ці санкції у теорії кримінального права прийнято іменувати безальтернативними відносно визначеними. Сенс таких юридичних конструкцій санкцій полягає в тому, що вони дозволяють суду визначити справедливе і достатнє покарання з урахуванням всіх обставин, які визначають загальні та спеціальні засади призначення покарання, тобто реалізувати одну із основоположних засад кримінального права - принцип індивідуалізації кримінальної відповідальності і покарання. Як зазначає 
Т.Денісова: «законодавець використовує в чинному кримінальному законодавстві відносно визначені й альтернативні санкції для диференціації відповідальності та індивідуалізації покарання, враховуючи саме особу винного, у противному разі переважали б абсолютно визначені санкції» [1, с.86]. Сучасна система вітчизняного кримінального права не сприймає абсолютно-визначених санкцій, оскільки вони належним чином не можуть інтегруватися і взаємодіяти із нормами інститутів призначення покарання. Досліджуючи питання обмеження суддівського розсуду при призначенні покарання, Ю. Лемішко зазначала, що абсолютно-визначені санкції можуть діяти у кримінальному законодавстві лише у разі впровадження максимальної фрормалізації процесу покарання, «коли встановлені в законі правила в кожному конкретному випадку доволі жорстко визначають обрання виду і розміру покарання за вчинений злочин» [2, с. 43]. 3а таких умов процесуальна робота судді щодо призначення покарання зводилася б лише до реєстрування сукупності юридично-значущих даних, на підставі яких, за певним алгоритмом він мав би вивести розмір покарання. Однак, невиправна вада алгебраїчних концепцій призначення покарання полягає у тому, що об'єктивно не можливо закріпити у фрормулах все різноманіття життєвих обставин, які впливають на призначення покарання, їх поєднання, доповнення, взаємовиключення тощо. Саме тому у вітчизняному праві відповідні дослідження не виходять за рамки утопічних юридичних концепцій.

Повертаючись до аналізу вад вказаних вище санкцій ст. 152, 153 КК України, спробуємо поставити себе на місце умовного опонента та навести аргументи на користь їх відповідності системі норм кримінального законодавства, якими визначаються правила призначення покарання. Тож почнемо.

Якщо поглянути на досліджувану санкцію, то ми бачимо, що поряд із позбавленням волі на строк п'ятнадцять років, законодавець передбачив можливість застосування покарання у вигляді довічного позбавлення волі. 3 огляду на таку компоновку їі необхідно віднести до альтернативних санкцій. Відтак твердження про те, що суд при застосуванні цієї санкції не зможе вдатися до індивідуалізації покарання є безпідставними, оскільки суддівський розсуд може бути реалізований шляхом вибору одного з цих покарань. Межі судової дискреції в даному випадку дещо звужені, однак все одно вони наявні, і дозволяють суду індивідуалізувати покарання. Наприклад, і за особливо кваліфіковану контрабанду (ч. 3 ст. 201 КК України) передбачається можливість застосування лише одного основного покарання - позбавлення волі на строк від десяти до дванадцяти років, що теж свідчить про вузькі рамки суддівського розсуду. Однак чим вища ступінь небезпечності вчиненого посягання, тим обгрунтованішим виглядає звуження законодавцем меж покарання.

На ці умовні аргументи можливо відповісти наступним. По-перше, фрормулювання строкового виду покарання без вказівки на нижню і верхню межі (або хоча б лише верхню) не застосовується у КК України. Їх відсутність у вітчизняному кримінальному законі ми пояснювали вище. Ще на етапі законодавчої розробки відповідних новацій юристи «били на сполох». Так у зауваженнях Головного юридичного управління до проекту цього закону зазначалося наступне: «абсолютно визначені санкції у чинному законодавстві відсутні і у науковій кримінально-правовій літературі їх наявність розглядається як прояв волюнтаризму при тоталітарних режимах» [3]. По друге, у разі наявності у санкції чинного КК України абсолютно визначеного покарання, їі доповнюють альтернативним відносно-визначеним покаранням (наприклад, 
санкція ч. 2 ст. 115 КК України поряд із довічним позбавленням волі передбачає можливість застосування до особи іншого основного покарання - позбавленням волі на строк від десяти до п'ятнадцяти років). По-трете, практика конструювання альтернативних санкцій з декількома абсолютно-визначеними покараннями залишилася у радянському минулому. Так, наприклад, ч. 2 ст. 256, ст. 257, 58 КК України 1960 р. передбачали покарання у вигляді довічного позбавлення волі або позбавленням волі строком на п'ятнадцять років [4]. Тому впровадження практики формулювання санкцій, запозичених із радянського кримінального законодавства, м'яко кажучи, є регресивним кроком, який по суті, перекреслює всі сучасні гуманітарні напрацювання юридичної науки.

Основна ж наша теза зводиться до того, що альтернативний характер впровадженої санкції в цілому є удаваним. Фактично ця санкція буде працювати як абсолютно-визначена безальтернативна. Річ у тім, що існує стала судова практика застосування покарання у вигляді довічного позбавлення волі, за якої суди призначають його, по-перше, лише за злочини, що пов'язані із умисним позбавленням життя, a, по-друге, найчастіше за наявності декількох кваліфрікуючих ознак умисного вбивства чи сукупності його з іншими особливо тяжкими злочинами. В цілому складно уявити ситуацію, за якою суд визнав би за необхідне за вчинення кваліфікованого повторного зґвалтування засудити особу до довічного позбавлення волі. Крім того, звертає на себе увагу і те, що жодна інша стаття КК України не передбачає таких самих механізмів кримінально-правової охорони інтересів малолітніх осіб. Це теж, в свою чергу, знецінює запропонований правозастувачу вид покарання за вчинення цих посягань.

Обираючи із двох запропонованих у санкції покарань єдине можливе до застосування - строкове позбавлення волі, суд і в цьому випадку не зможе ефективно його застосувати, оскільки як слушно зазначається у зауваженнях Головного юридичного управління ВРУ, абсолютно визначена санкція позбавляє суд можливості, вивчивши усі обставини справи, особу обвинуваченого, інші обставини, що можуть мати вплив на призначення покарання, визначити вид і міру покарання належного і достатнього для досягнення мети кримінальної відповідальності, а це в свою чергу негативним чином впливає на ефективність кримінально-правового регулювання в цілому [3]. Законодавець створив штучні умови, за яких для того, що б досягнути мети покарання, реалізувати засади індивідуалізації покарання суду доведеться вдаватися до застосування кримінально-правових інститутів, які передбачають правові механізми виходу за межі санкції статті при призначенні покарання (наприклад ст. 69 КК України).

У якості «родзинки» досліджуваного посилення відповідальності позначимо ситуацію, за якою взагалі неможливо буде застосувати до винного покарання. Так у разі вчинення повторного зґвалтування малолітньої особи неповнолітнім буде мати місце певна специфріка призначення йому покарання. Так, в силу припису, якій міститься у ч. 2 ст. 64 КК України, застосувати до нього довічне позбавлення волі буде de јure не можливо. А з урахуванням спеціальної норми Розділу XV Загальної частини КК України і покарання у виді 15 років позбавлення волі до нього не застосовується. В силу ч. 3 ст. 102 КК України за вчинення особливо тяжкого злочину, не поєднаного з умисним позбавленням життя людини, неповнолітня особа може бути засуджена на строк не більше десяти років позбавлення волі. Ця норма виписана з урахуванням застосування відносно-визначеного покарання - позбавлення волі на певний строк і не може 
бути застосована до його незвичайного еквіваленту - абсолютно-визначеного строкового позбавлення волі. На допомогу суду у цьому випадку не зможуть прийти і пільгові інститути, використовуючи які, можливо було б «знизити» міру покарання до максимально допустимого розміру - 10 років. На заваді цьому стоїть усталений правовий алгоритм, визначений для таких ситуацій у Постанові ПВСУ «Про практику призначення судами кримінального покарання» від 24.10.2003 р. № 7. У абз. 7 п. 8 цієї постанови зазначається, що «суд не вправі перейти до більш м'якого виду покарання у випадках, коли санкцією закону, за яким засуджується особа, передбачено лише такі покарання, які з огляду на її вік чи стан не можуть бути до неї застосовані. В таких випадках суд, за наявності до того підстав, відповідно до ст. 7 КПК повинен закрити справу і звільнити особу від кримінальної відповідальності або постановити обвинувальний вирок і звільнити засудженого від покарання» [5].

Відтак ми маємо взірець «шкідництва» з боку законодавця, пов'язаний із тим, що окремі представники законодавчого органу, не маючи жодних уявлень про особливості побудови кримінального закону, особливості його систему, взаємозв'язок кримінально-правових норм, своїми законодавчими ініціативами лише спотворюють КК України.

\section{Список використаних джерел:}

[1] Денисова, Т. А. (2011) Поняття кримінально-правової санкції. Право та державне управління, (1), 81-86.

[2] Лемішко, Ю. Ю. (2017). Способи обмеження суддівського розсуду при призначенні покарання. Судова та слідча практика в Україні. (5), 42-48.

[3] Зауваження Головного юридичного управління 21.10 .2019 p. (2019). Вилучено з: http://w1.c1.rada.gov.ua/pls/zweb2/webproc4_2?pf3516=0887\&skl=10

[4] Кримінальний кодекс України (Закон УРСР від 28.12.60). (1960). Вилучено з: https://zakon.rada.gov.ua/laws/show/2002-05/ed19960807\#Text

[5] Про практику призначення судами кримінального покарання (Постанова пленуму Верховного суду України від 24.10.2003 р. № 7). (2003). Вилучено з: https://zakon.rada.gov.ua/laws/show/v000770003\#Text 
Président du comité d'organisation: Holdenblat $M$.

Responsable de la mise en page: Bilous $T$.

Responsable de la conception: Bondarenko I.

\section{T 35 Tendances scientifiques de la recherche fondamentale et} appliquée: collection de papiers scientifiques «^ОГО $\Sigma$ » avec des matériaux de la conférence scientifique et pratique internationale (Vol. 2), 30 octobre, 2020. Strasbourg, République française: Plateforme scientifique européenne.

ISBN 978-2-37467-128-4 («La Fedeltà», République française)

DOI 10.36074/30.10.2020.v2

Les résumés et articles des participants à la conférence multidisciplinaire scientifique et pratique internationale "Tendances scientifiques de la recherche fondamentale et appliquée», qui s'est tenue à Strasbourg le 30 octobre 2020, sont présentés.

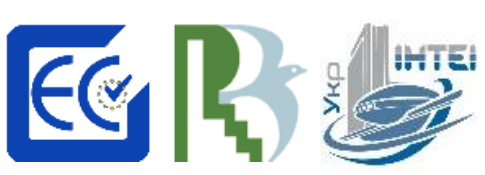

La conférence est incluse dans le catalogue des conférences scientifiques internationales; approuvé par ResearchBib et UKRISTEI (Certificat № 450 du 05/10/2020); est certifié par Euro Science Certification Group (Certificat № 22182 du 04/10/2020).

Le matériel de la conférence sera accessible au public selon les termes de la licence Creative Commons Attribution 4.0 International (CC BY 4.0).

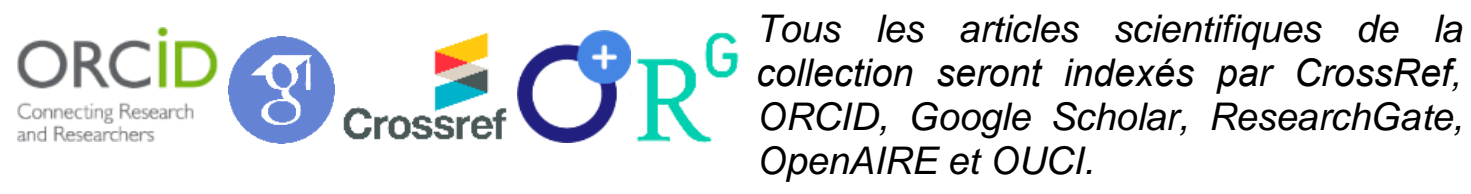

UDC $001(08)$

(C) Le collectif des participants à la conférence, 2020

(C) Collection de papiers scientifiques «^ОГОО $», 2020$ 